\title{
ANALISA USAHA BUDIDAYA UDANG VANNAMEI (Lithopenaeus vannamei) DAN IKAN BANDENG (Chanos-chanos $S p$.) DI DESA SIDOKUMPUL KECAMATAN LAMONGAN KABUPATEN LAMONGAN JAWA TIMUR
}

\author{
Wachidatus Sa'adah \\ DOSEN UNISLA
}

\begin{abstract}
ABSTRAK
Dewasa ini arah pembangunan perikanan telah berubah dari perikanan tangkap ke perikanan budidaya. Perubahan trend tersebut disebabkan karena manusia semakin memahami bahwa sumber daya ikan yang menjadi target penangkapan semakin berkurang (Djoni Irianto dan Wiwik Heny Winarsih, 2001). Perkembangan tehnologi bandeng sangat lambat jika dibanding udang, hasilnya sering rugi. Sesuai dengan perkembangan zaman, budidaya udang vannamei diharapkan bisa menaikkan produksi,, menaikkan pendapatan bahkan meningkatkan kelayakan hidup masyarakat.

Penulis melakukan penelitian di Desa Sidokumpul Kecamatan Lamongan Kabupaten Lamongan. Penelitian ditujukan untuk mengetahui kelayakan usaha budidaya udang vannamei dan ikan bandeng dan menguntungkan untuk diusahakan. Penelitian ini menggunakan studi kasus. Data yang langsung dari sumbernya dengan cara observasi 1 partisipasi aktif dan wawancara dan data sekunder ialah data yang diperoleh tak langsung misalnya buku literatur, monografi desa dan lain-lain. Analisa yang digunakan adalah Imbang Penerimaan atau R/C Ratio, Analisa Titik Impas dan Rentabilitas. Sampel yang diambil 15 orang petani tambak. Ternyata disimpulkan bahwa usaha budidaya udang vannamei dan ikan bandeng layak dan menguntungkan untuk diusahakan dengan hasil sebagai berikut : $R / C$ Ratio $=1,7$, Rentabilitas rata-rata 69,96\%, dan BEP (Analisa Titik Impas) $=2,868427$
\end{abstract}

\section{Kata Kunci : Analisa Usaha, Budidaya Udang Vannamei, Ikan Bandeng}

\section{A. Latar Belakang}

Sektor perikanan memiliki sumberdaya yang sangat potensial sebagai sumber potensi baru, seiring dengan semakin berkurangnya sumberdaya pada sektor pertanian yang banyak digunakan untuk berbagai kegiatan ekonomi yang lain. Potensi sumberdaya ikan yang terkandung dalam wilayah perairan nasional memiliki tingkat keanekaragaman hayati yang paling tinggi, yaitu $37 \%$ dari spesies ikan yang ada di dunia. Hal ini memberi gambaran betapa besarnya potensi perikanan di Indonesia (Anonymous, 1993)

Budidaya ikan bandeng (Chanos-chanos) telah lama dilakukan di Indonesia, terutama untuk kebutuhan konsumsi. Bandeng memiliki sifat euryhaline sehingga dapat dibudidayakan di air asin, payau, dan tawar. Perkembangan teknologi budidaya bandeng berjalan sangat lambat jika dibandingkan dengan udang. Hasilnya pun sering kali rugi.

Budidaya udang vannamei (lithopenarus vannamei) merupakan salah satu alternatif pemecahan untuk mengatasi kegagalan budidaya bandeng dengan upaya pergantian varietas di sektor perikanan, dimana species ini lebih tahan terhadap penyakit. (Anonymous, 2003).

Udang vannamei secara resmi ditetapkan sebagai komoditas unggulan perikanan budidaya oleh Menteri Kelautan dan Perikanan pada tahun 2001 dan mengalami perkembangan yang sangat cepat. (Anonymous, 2004).

Di Desa Sidokumpul Kecamatan Lamongan terdapat usaha budidaya udang vannamei dan bandeng dan usaha ini masih dalam taraf percobaan maka dari itu perlu dilakukan analisis apakah usaha budidaya udang vannamei dan bandeng yang sudah ada menguntungkan atau tidak dari segi ekonomis.

Perumusan Masalah

Dari latar belakang dirumuskan masalah sebagai berikut ;

1. Bagaimana gambaran budidaya udang vannamei dan ikan bandeng ?

2. Bagaimana kelayakan usaha budidaya udang vannamei dan ikan bandeng dan menguntungkan untuk diusahakan ?

\section{Tujuan Penelitian}

Tujuan dari penelitian ini adalah :

1. Untuk mendapatkan gambaran / tentang usaha budidaya vannamei dan ikan bandeng.

2. Untuk mengetahui kelayakan usaha budidaya udang vannamei dan ikan bandeng sehingga bisa diketahui apakah usaha budidaya udang vannamei dan ikan bandeng layak dan menguntungkan untuk diusahakan.

\section{Kegunaan Penelitian}

Hasil penelitian ini diharapkan memberikan kegunaan :

1. Sebagai media latih bagi penulis untuk membahas masalah yang ada pada penelitian yang penulis lakukan.

2. Sebagai tambahan informasi bagi kepustakaan Fakultas Perikanan Unisla yang bisa dijadikan penelitian berikutnya yang masih berkaitan dengan masalah tersebut. 


\section{Hipotesa Penelitian}

Diduga bahwa usaha budidaya udang vannamei dan ikan bandeng Desa Sidokumpul Kecamatan Lamongan Kabupaten Lamongan Jawa Timur adalah layak dan menguntungkan untuk diusahakan.

\section{B. Tinjauan Pustaka}

\section{Biologi Udang Vannamei}

Ciri-ciri Udang Vannamei :

- Warna bening kecoklatan atau kehitamhitaman

- Kulit licin, lebih tipis dari udang windu

- Jika stres berwarna putih kapas

- Meloncat jika ada kejutan cahaya

- Kanibalisme rendah

- Tempat hidup didasar dan melayang dalam air (dapat ditebar dengan kepadatan tinggi $>100$ ekor $/ \mathrm{m}^{2}$ )

- Suka mengaduk dasar kolam

- Kebutuhan kadar protein 30-32 \%

- Nafsu makan sangat rakus, namun fluktuatif

- Nafsu makan dikontrol lewat anco

- Saat panen melawan arus, banyak tertinggal

Kelebihan Udang Vannamei adalah :

- Cara budidaya relatif lebih mudah

- Reatif tahan terhadap penyakit

- Harga jual relatif lebih tinggi

- Produktifitas tinggi

\section{Biologi Ikan Bandeng}

Menurut Ghufron, M. (1997), ikan bandeng (Chanos-chanos) diklasifika-sikan sebagai berikut :

Filum : Chordata

Klas : Pisces

Ordo : : : Calacopterygii

Family : Chanidae

Genus : Chanos

Species : Chanos-chanos

Bandeng mempunyai ciri-ciri : ekor bercak, badan memanjang kepala tanpa gigi, lubang hidung terletak di depan mata, mata diselaputi oleh selaput bening, sirip punggung terletak jauh di belakang tutup insang dan tubuhnya ditutupi oleh sisik-sisik kecil. Memiliki sirip punggung 14-16, sirip dada 16-17, sirip perut 11-12 dan sisik garis rusuk sebanyak 75-80 buah.

Selain itu ciri khas lain dari deskripsi ikan bandeng ini adalah warna badan hijau keperakan di bagian atas, kepekaan di bagian tengah serta putih bawah di bagian bawah. Panjangnya dapat mencapai $75 \mathrm{~cm}$ (Anonymous, 2000).

\section{Operasional Pembesaran Udang Vannamei dan Bandeng \\ - Penebaran Benih}

Kematian benih udang vannamei dan benih bandeng sering disebabkan oleh karena stress pada waktu penanganan, karena perubahan lingkungan yang mendadak. Untuk mengatasi hal tersebut maka dilakukan aklimatisasi yaitu mencampurkan air dari wadah pengangkut dan air tambak pada bak plastik yang dilakukan secara bertahap. Aklimatisasi dihentikan jika benih udang vannamei dan bandeng sudah bergerak lincah (2-3 jam). Kemudian benih secara perlahan ditebar ke petak tambak.

- Pengelolaan Kualitas Air

Pengelolaan kualitas air merupakan suatu hal yang mendapat perhatian utama terutama di tambak yang kepadatannya tinggi karena penurunan kualitas air berakibat buruk terhadap pertumbuhan dan kehidupan udang vannamei dan bandeng. Kualitas air yang baik untuk kehidupan dan pertumbuhan udang dan ikan ialah Suhu : $28^{\circ} \mathrm{C}, \mathrm{PH}$ adalah 7,5-9, oksigen terlarut 5-9 ppm, salinitas 5-10 promil. (Kungvankij, et al, 1986).

- Pemberian Pakan Pemberian pakan dalam budidaya udang atau ikan bertujuan untuk meningkatkan efisiensi pakan yang digunakan dan meminimalkan limbah pakan dalam tambak. Langkah yang harus diterapkan antara lain :

1) Pakan tidak kadaluarsa dan memenuhi gizi standart nutrisi sesuai dengan SNI.

2) Pakan harus bermutu baik dan tidak mengandung penyakit.

3) Mengamati konsumsi setiap pemberian akan dengan ancho.

- Pemasaran dan Pasca Panen

Menurut Mudjaman A. (1988) bahwa pemeliharaan ikan atau udang biasanya berlangsung 5-6 bulan. Tetapi bila kondisi tambak baik, pengelolaan sampai 3-4 bulan bisa dipanen sebagian dan sisanya dipanen total. Setelah udang dan bandeng dipanen maka diadakan pencucian bersih dan diadakan pemilihan untuk udang dimasukkan blong ditambah es, sedangkan ikan bandeng dimasukkan dalam keranjang ditata secara teratur (Anonymous, 2003)

\section{- Pemasaran}

Menurut Hanafiah AM dan Saifuddin Am, 1983 pemasaran sering disebut penjualan. Sasaran pemasaran adalah memindahkan barang dari penjual ke pihak pembeli dengan harga yang memuaskan. 


\section{Biaya Usaha}

Biaya usaha disini adalah merupakan biaya investasi dan biaya operasional yang dibutuhkan selama umur usaha melakukan kegiatan produksi (Soekartawi, 2002).

Biaya yang digunakan pada usaha budidaya udang vannamei dan ikan bandeng ialah :

- Biaya tetap

Ialah biaya yang penggunaannya tidak habis dalam satu masa produksi termasuk tambak dan pompa air.

- Biaya variabel

Ialah biaya yang jumlahnya berubah-ubah tergantung skala produksi per siklus, termasuk : benih, pakan, kapur, pupuk, bahan bakar / bensin / solar.

\section{Analisa Usaha}

Data yang menunjang aspek ekonomis meliputi :

a. Revenue Cost Ratio (R/C)

Ialah perbandingan total penerimaan yang diperoleh dengan total biaya yang dikeluarkan (Soekartawi, 2002)

$\mathrm{R} / \mathrm{C}=\frac{\mathrm{TR}}{\mathrm{TC}}$

Dimana : TR : Total penerimaan

TC : Total cost / total biaya

b. Analisa Titik Impas (BEP)

Ialah analisis titik impas dimana dapat diperhitungkan batas kwantitas produksi yang mengalami keuntungan dan kerugian pada usaha perikanan yang dilakukan petani atau nelayan (Riyanto B, 2006)

$$
\mathrm{BEP}=\frac{\mathrm{FC}}{1-\mathrm{VC} / \mathrm{TR}}
$$

Dimana : FC : Fixed cost (biaya tetap keuntungan)

VC : Variabel cost / biaya variabel

TR : Total revenue / total penerimaan

c. Rentabilitas

Ialah perbandingan antara laba dari kegiatan usaha tani (keuntungan) dengan seluruh modal yang digunakan dalam usaha tani tersebut.

$$
\text { Rentabilitas }=\frac{\text { Laba }}{\text { Total Modal }} \times 100
$$

\section{Materi dan Metode Penelitian \\ - Materi Penelitian}

Materi penelitian ini adalah petani tambak yang melakukan usaha budidaya udang vannamei dan ikan bandeng di Desa Sidokumpul Kecamatan Lamongan.

\section{- Metode Penelitian}

Metode penelitian ini adalah metode kasus dimana peneliti akan mendapat gambaran yang luas dan lengkap dari subyek yang diteliti, karena ada anggapan bahwa sifat-sifat individu merupakan gambaran dari individu yang lain maka hasil dari studi kasus dengan metode analisa sering kali dijadikan hipotesis bagi suatu penelitian yang meliputi daerah dan populasi yang lebih luas.

\section{- Sumber Data}

Jenis data yang digunakan dalam penelitian ini adalah data primer dan data sekunder.

Data primer adalah data yang diperoleh langsung dari sumbernya dengan cara observasi, partisipasi aktif dan wawancara.

- Observasi adalah melakukan pengamatan secara sistematis terhadap segala yang diteliti.

- Partisipasi aktif adalah mengikuti secara langsung segala kegiatan yang ada di dalam usaha budidaya udang vannamei dan ikan bandeng.

- Wawancara ialah mengikuti / mengadakan tanya jawab secara langsung kepada petugas terkait dan petani yang melakukan usaha budidaya udang vannamei dan ikan bandeng.

Data sekunder ialah data yang diperoleh tidak langsung dan sumbernya diambil dari buku literatur, monografi desa, statistik Dinas PKP dan lain-lain yang digunakan untuk melengkapi data primer.

\section{- Cara Pengambilan Sampel}

Di Desa Sidokumpul Kecamatan Lamongan terdapat 105 orang yang melakukan usaha budidaya. Namun yang melakukan usaha budidaya udang vannamei dan ikan bandeng berjumlah 50 orang.

Untuk lebih menyeragamkan responden yang diambil serta untuk lebih memudahkan dalam penganalisaannya maka ditetapkan syaratsyarat.

- Lahan usaha luasnya 1 ha.

- Formulasi pakan teratur

Dari petani tambak 50 orang yang memenuhi persyaratan berjumlah 15 orang.

\section{- Analisis Data}

Analisis data adalah suatu proses penyederhanaan data ke dalam bentuk yang lebih mudah dibaca dan diinterpretasikan. Data yang telah terkumpul dalam penelitian kemudian diolah dan dianalisa sesuai dengan tujuan penelitian.

Metode analisis data yang digunakan dalam penelitian ini adalah imbangan penerimaan dan biaya, analisa titik impas serta rentabilitas.

\section{Hasil dan Pembahasan}




\section{Keadaan Umum Daerah Penelitian} Letak dan Geografis Daerah Penelitian

Penelitian dilaksanakan di Desa Sidokumpul Kecamatan Lamongan Kabupaten Lamongan Jawa Timur. Desa Sidokumpul adalah desa di daerah perkotaan yang jaraknya $1 \mathrm{~km}$ dari Kabupaten Lamongan. Lama tempuh ke ibukota kabupaten terdekat 0,15 jam. Jarak ke kecamatan $1,5 \mathrm{~km}$ dengan lama tempuh 0,25 jam.

Daerah termasuk dataran dengan ketinggian 7 $\mathrm{m}$ dari atas permukaan air laut dengan curah hujan $2.000 \mathrm{~mm} / \mathrm{th}$.

Wilayah batas Desa Sidokumpul adalah :

Sebelah utara : Desa Glugu Kecamatan Deket

Sebelah Selatan : Kelurahan Jetis Kecamatan Lamongan

Sebelah Barat : Desa Tumenggungan Kecamatan Lamongan

Sebelah Timur : Desa Banjarmendalan Kecamatan Lamongan

Luas Desa Sidokumpul Kecamatan Lamongan Kabupaten Lamongan $=496,227$ ha. Luas sawah tambak 236 ha. Hampir separuh dari luas Desa Sidokumpul sebagai sawah tambak, kondisi alamnya yang demikian memungkinkan sekali untuk mengembangkan usaha perikanan yaitu usaha sawah tambak.

\section{Usaha Budidaya Udang Vannamei dan Ikan Bandeng}

Usaha budidaya udang vannamei dan ikan bandeng di Desa Sidokumpul Kecamatan Lamongan yang dilakukan petani tambak termasuk semi intensif disebabkan penggunaan pakan alami dan pakan buatan, pergantian air dengan memompa air lebih dari 10 kali. Tambak yang dikelola berukuran 1 ha. Hal ini menurut Taufik A. (1988) bahwa persyaratan tehnik tambak udang, untuk tambak semi intensif berukuran $0,5-1$ ha dan pergantian air 5 sampai 20 kali, pakan buatan dan pakan alami, padat penebaran $10-25 / \mathrm{m}^{2}$.

Tabel : Data Produksi dari udang vannamei dan ikan bandeng per hektar masing-masing petani tambak

\begin{tabular}{|c|c|c|c|}
\hline \multirow[b]{2}{*}{ No } & \multirow[b]{2}{*}{$\begin{array}{c}\text { Nama Petani } \\
\text { Tambak }\end{array}$} & \multicolumn{2}{|c|}{ Produksi (kg) } \\
\hline & & $\begin{array}{c}\text { Udang } \\
\text { Vannamei }\end{array}$ & $\begin{array}{c}\text { Ikan } \\
\text { Bandeng }\end{array}$ \\
\hline 1 & Sutisno & 400 & 100 \\
\hline 2 & H. Abdullah & 500 & 100 \\
\hline 3 & H. Bonari & 400 & 100 \\
\hline 4 & Ach. Fuad & 300 & 100 \\
\hline 5 & Said & 200 & 100 \\
\hline 6 & Sunari & 250 & 90 \\
\hline 7 & Sumijan & 400 & 75 \\
\hline
\end{tabular}

\begin{tabular}{|c|c|c|c|}
\hline 8 & Abdul Rohman & 300 & 100 \\
\hline 9 & Subeki & 200 & 100 \\
\hline 10 & Seno & 300 & 100 \\
\hline 11 & Sunaryo & 350 & 100 \\
\hline 12 & Tikno & 300 & 120 \\
\hline 13 & Ali & 500 & 100 \\
\hline 14 & Sumitro & 500 & 100 \\
\hline 15 & Sudiono & 300 & 150 \\
\hline \multirow{2}{*}{\multicolumn{2}{|c|}{ Jumlah }} & 5200 & 1535 \\
\hline & & 346,7 & 102,3 \\
\hline
\end{tabular}

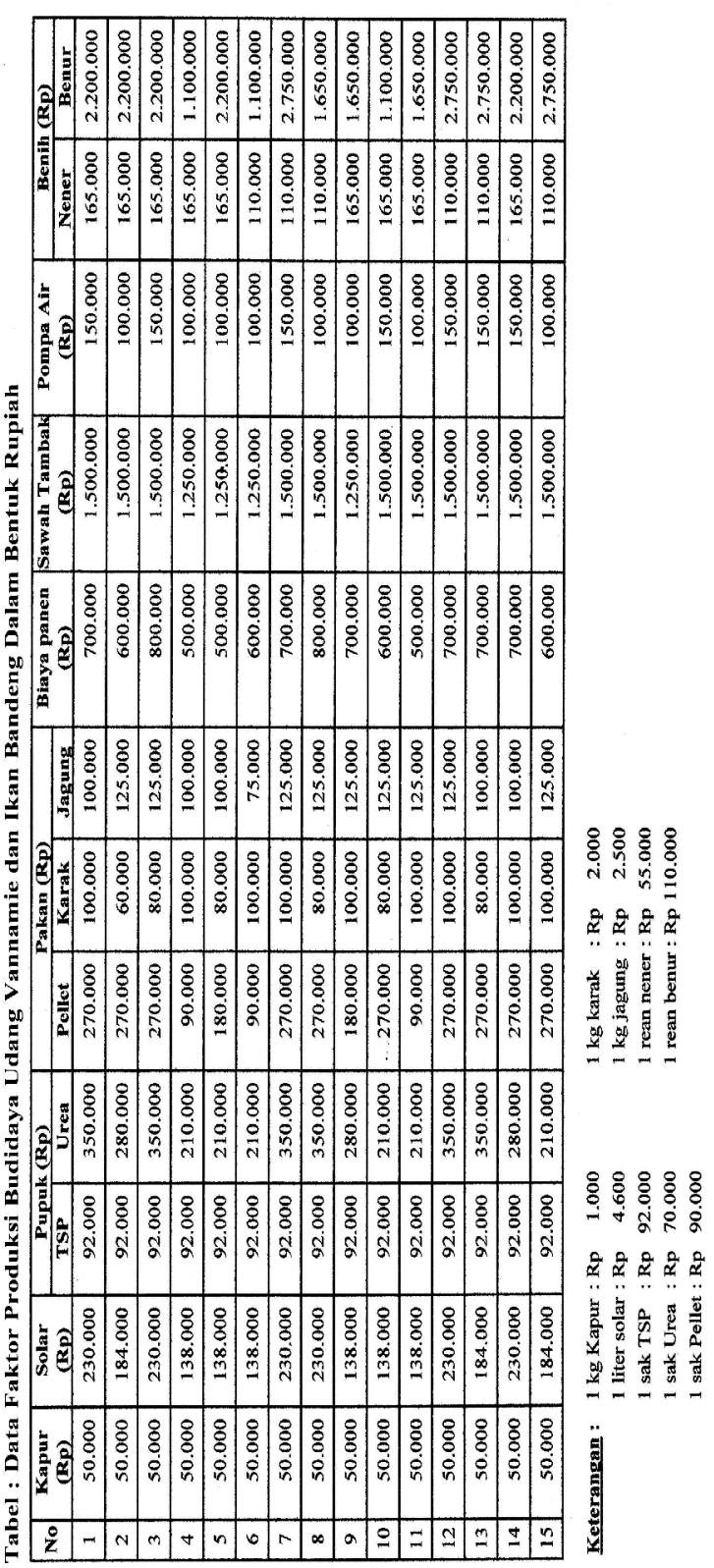




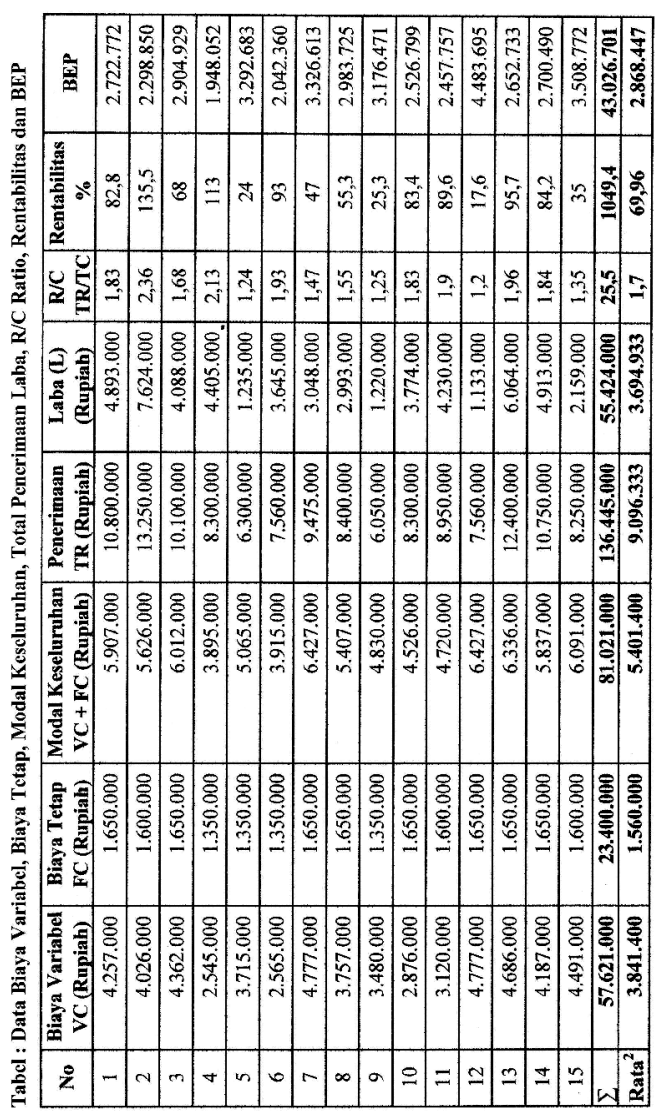

3. Keragaan Budidaya Udang Vannamei dan Ikan Bandeng di Desa Sidokumpul Kecamatan Lamongan

Untuk meningkatkan produk dari budidaya udang vannamei dan ikan bandeng antara lain adalah :

- Persiapan tambak

Sebelum benih ditebar di tambak, tanah tambak diolah lebih dahulu. Adapun pengolahan tambak adalah petakan tambak mula-mula dikeringkan dan lumpurnya dikeluarkan untuk mempertinggi dan menutupi kebocoran dari pematang selanjutnya tanah dibajak

- Setelah selesai pengolahan, tambak dikeringkan sampai retak-retak \pm 15 hari tergantung cuaca. Selama proses pengeringan dilakukan kegiatan perbaikan pematang pembersihan caren dan pematang dasar tambak.

- Setelah itu tanah tambak perlu dikapur. Tanah dalam keadaan macak-macak saat diadakan pengapuran.

- Sehari setelah pengapuran maka tanah tambak dipupuk. Caranya sewaktu tanah tambak masih dalam keadaan basah / macak-macak pupuk ditebar secara merata di permukaan tambak. Pemupukan dilakukan beberapa kali untuk menambahkan pakan alami.
- Kemudian tambak diairi setinggi 70-100 $\mathrm{cm}$. air didapat dari muara sungai Bengawan Solo dan air hujan.

- Penyediaan benih adalah faktor yang sangat penting dalam usaha budidaya udang atau ikan.

Benih ikan bandeng (nener) dibeli di tempat pemasaran benih yang berjarak $3 \mathrm{~km}$ (di Desa Pandanan). Nener yang dibeli berukuran $1 \mathrm{~cm}$ dengan harga $\mathrm{Rp} 65.000$,setiap reannya. Benih diangkut dengan kantong plastik. Sedang benih udang vannamei (benur) berasal dari $\mathrm{F} 1$ dari $\mathrm{CP}$ Prima dengan ukuran $\pm 1 \mathrm{~cm}$ setiap reannya. Penebaran benih dilakukan pagi hari pukul 06.00 WIB atau pukul 17.00 WIB. Karena pada saat itu suhu air tambak rendah, kandungan oksigennya terlarut baik berasal dari hasil proses asimilasi pada siang hari.

Benih yang ditebar untuk 1 ha tambak untuk udang vannamei 10 rean sampai dengan 25 rean sedangkan bandeng 2-3 rean per hektarnya.

- Selama masa pemeliharaan dilakukan, kontrol kualitas air antara lain suhu, oksigen, $\mathrm{PH}$, salinitas, kecerahan disamping itu benih juga diberi makan.

Ikan yang diberikan pada tambak udang vannamei dan ikan bandeng adalah pakan alami dari pemupukan.

Sedangkan pakan buatan berupa pellet serta makanan tambahan berupa jagung dan karak. Pemberian pakannya dilakukan setiap hari. Pengaturan air dilakukan 3-4 hari sekali dengan memompa air.

Untuk mengetahui kepadatan stock udang vannamei dan ikan bandeng dalam tambak serta untuk mengetahui ukuran udang vannamei dan ikan bandeng untuk konsumsi maka dilakukan sampling. Penangkapan dengan ancho kemudian ditambang untuk diketahui jumlah udang per $\mathrm{kg}$. Masa pemanenan udang vannamei dan ikan bandeng adalah 3 bulan. Udang vannamei berjumlah 90-100 per kilogram dan ikan bandeng berjumlah 10 per $\mathrm{kg}$. Setelah udang vannamei dan ikan bandeng dipanen maka diadakan pencucian dengan air kemudian udang vannamei dan ikan bandeng diadakan pemilahan. Untuk ikan bandeng dimasukkan ke dalam keranjang secara teratur sedangkan udang vannamei dimasukkan dalam blong serta diberi es.

Kemudian udang vannamei dan ikan bandeng diadakan penimbangan. Setelah itu dibawa ke pasar ikan Lamongan untuk dijual.

\section{Biaya Produksi / Biaya Usaha}

Biaya yang digunakan oleh seluruh responden adalah biaya sendiri dari harta kekayaan pribadi. Lahan yang digunakan dinilai dalam 
bentuk harga sewa tanah tersebut di pasaran saat ini yaitu antara Rp 5.000.000,sampai dengan Rp 6.000.000,per tahun per ha.

Biaya yang digunakan meliputi biaya tetap antara lain tanah, pompa air, waring seser, gayung dan lain-lain. Dan biaya variabel antara lain ialah membeli benih, membeli kapur, solar, pupuk urea atau TSP, pakan pellet, jagung, karak, biaya panen.

\section{R/C Ratio}

$\mathrm{R} / \mathrm{C}$ Ratio adalah merupakan perbandingan antara total penerimaan dengan total biaya (Soekartawi, 2001). Dari penelitian dihasilkan bahwa $\mathrm{R} / \mathrm{C}$ ratio rata-rata $=1,7$. Berarti setiap Rp 100,- yang dikeluarkan kegiatan usaha diperoleh penerimaan sebesar Rp 170,- hasil ini disebabkan faktor produksi bagus, pemilihan benih baik, aklimatisasi benih terhadap lingkungan juga baik.

\section{Rentabilitas}

Rentabilitas (RE) suatu perusahaan menunjukkan perbandingan antara laba dengan modal yang menghasilkan laba atau kemampuan perusahaan untuk menghasilkan laba selama periode tertentu. Dari penelitian diperoleh hasil RE rata-rata $=69,96 \%$. Hal ini disebabkan petani tambak dalam mengolah tambaknya memperhatikan pengolahan tanah, aklimatisasi benih terhadap lingkungan tambak, pengaturan air, pemberian makanan tambahan atau buatan sehingga menghasilkan produksi yang tinggi. Dilihat dari rentabilitas tersebut berarti budidaya udang vannamei dan ikan bandeng tersebut layak diusahakan.

\section{Analisa Titik Impas (BEP)}

Analisa Break Even Point adalah tehnik untuk mempelajari hubungan antara biaya tetap, biaya variabel, keuntungan, dan volume kegiatan. BEP mendasarkan pada hubungan antara biaya (cost) dan penghasilan penjualan (revenue). Apabila suatu perusahaan hanya mempunyai biaya variabel maka tidak akan muncul masalah BEP, masalah baru muncul jika perusahaan memiliki biaya tetap. (Husnan S., Suwarsono, 1994)

Dari penelitian didapatkan bahwa hasil BEP rata-rata adalah $\mathrm{Rp}$. 2.868.447,-. Ini berarti bahwa petani tambak mengalami impas bila total penerimaan sebesar

$\mathrm{Rp}$ 2.868.447,-- dengan kata lain petani tambak tidak untung dan tidak rugi. Dari hasil penelitian semua petani tambak pada dasarnya BEP lebih kecil dari total penerimaan, ini berarti petani tambak mempunyai keuntungan dalam mengolah tambaknya. Petani selalu memperhatikan dalam pengolahan tanah, pemilihan benih dan aklimatisasi terhadap lingkungan, pemberian pupuk, pemberian pakan, pengaturan air sehingga diperoleh produksi yang tinggi, berarti pula usaha budidaya udang vannamei dan ikan bandeng layak untuk diusahakan.

\section{Kwalitas Air}

Dari hasil penelitian pengamatan kwalitas air adalah suhu $29^{\circ} \mathrm{C}-31^{\circ} \mathrm{C}$, PH adalah 6-7,5, salinitas $10-15$ promil dan hal tersebut layak untuk usaha budidaya

\section{E. Kesimpulan}

Berdasarkan hasil penelitian dapat disimpulkan bahwa usaha budidaya udang vannamei dan ikan bandeng layak dan menguntungkan untuk diusahakan. Usaha yang dilakukan pemilik tambak tergolong semi intensif ditinjau dari luas lahan dan pemberian pakan alami dan pakan buatan.

Dari analisa ekonomi diperoleh hasil sebagai berikut : Ratio Cost (R/C) rata-rata 1,7, Rentabilitas rata-rata $69.96 \%$, dan Analisa Titik Impas (BEP) : 2,868,427.

\section{REFERENSI}

Anonymous (2003). Informasi Budidaya Udang Vannamie Semi Intensif, Tradisional Plus di Jawa Timur. PT. Central Protein Prima.

Anonymous (2005). Petunjuk Teknik Budidaya Udang Vannamie yang Berkelanjutan. Departemen Kelautan dan Perikanan. Balai Besar Pengembangan Budidaya Air Payau Jepara

Anonymous, (1993). Pengelolaan Air Untuk Tambak. Direktorat Jenderal Perikanan Departemen Pertanian Jakarta.

Djoni Irianto dan Wiwik Heny Winarsih. (2001). Diseminasi Tehnologi Budidaya Laut di Jawa Timur, Jurnal Litbang, Sumber Daya Alam dan Tehnologi, Volume 1 No. 1 Agustus 2001, Badan Penelitian dan Pengembangan Propinsi Jawa Timur. Surabaya.

Hanafiah, AM dan Saefuddin AM. (1983). Tata Niaga Hasil Perikanan, Universitas Indonesia.

Kungvankij and TE. Chua J. Pudadera. (1986). Shrimp Culture, Operation and Management Network Aquaculture Centres in Asia BangkokThailand. Diterjemahkan Hardjono M. AM dan Suyanto.

Mudjiman, A. (1988). Budidaya Udang Windu. Penebar Swadaya.

Rahardi F, dkk. (2001). Agribisnis Perikanan. PT. Penebar Swadaya. Jakarta. 
Riyanto. (2006). Struktur Pembelajaran Perusahaan. PT. Gahlia. Jakarta.

Soekartawi. (2002). Agribisnis Teori \& Aplikasinya. PT. Raja Grafindo Persada. Jakarta.
Taufik, A. (1988). Seminar Budidaya Udang Intensif Peubah Penting Mutu Air Tambak Udang. Patra Utama Human Resources Development. 